\title{
Estimating machine impact on strip roads via close-range photogrammetry and soil parameters: a case study in central Italy
}

\author{
Martina Cambi ${ }^{(1)}$, \\ Francesca Giannetti ${ }^{(1)}$, \\ Francesca Bottalico(1), \\ Davide Travaglini ${ }^{(1)}$, \\ Tomas Nordfjell (2), \\ Gherardo Chirici (1), \\ Enrico Marchi ${ }^{(1)}$
}

\begin{abstract}
Several studies have been carried out to investigate soil compaction and rutting after logging vehicle traffic, based on time consuming and punctual field measurements. The objective of this study was to measure soil disturbances with two methods: (i) a new, image-based models derived by a structure-frommotion (SfM) photogrammetry approach; and (ii) a traditional soil sampling (bulk density and shear strength). Two trails were selected in a logging area (central Italy), one trafficked by a forwarder (FT) and one trafficked by a skidder (ST). Data collection was conducted before, during and after timber extraction. Image-based models derived by SfM photogrammetry was used to highlight the differences in the shape and distribution of the disturbances along ST and FT. Results showed that the physical parameters of soil significantly changed due to both FT and ST traffic. Machine passes increased bulk density $(111 \%$ and $31 \%$ for FT and ST, respectively), penetration resistance (29\% and $24 \%$ for FT and ST, respectively) and shear resistance $(14 \%$ and $6 \%$ for FT and ST, respectively), whereas porosity decreased ( $46 \%$ and $9 \%$ for FT and ST, respectively). Significant differences between FT and ST were found when comparing ruts removal and bulges with SfM photogrammetry. After logging, FT clearly showed ruts and bulges, whereas in ST ruts and bulges were not visible, but soil displacement in the direction of extraction was evident and measurable. Nevertheless, although our result shows a larger soil disturbance caused by forwarders than skidders, it is not possible to draw any general conclusions about differences between the two machines. Data about the machine passes, or the wood volumes transported over each trial area were not available; therefore, any general conclusion is misleading. SfM photogrammetry give information not available via traditional methods, thus improving impact assessment.
\end{abstract}

Keywords: Forest Operation, Soil Impacts, Soil Displacement, Close Range Photogrammetry, Digital Terrain Model

\section{Introduction}

Forest operations are recognized as sources of soil disturbance and erosion and have been the subject of much research since the 1950 s (Cambi et al. 2015). In particular, machine trafficking causes soil compaction (Jamshidi et al. 2008) and rutting, and is one of the major sources of humaninduced forest soil degradation (Gomez et al. 2002, Bagheri et al. 2013). The pressure exerted by loaded vehicles moving through the forest is a major factor causing compaction and rut formation (McNabb et al. 2001, Alakukku et al. 2003, Nugent et al. 2003, Eliasson 2005). In the last decades, the weights of forestry machines have increased, thus raising new concern over forest soil degradation (Sheridan 2003). Skid trails are forest areas prone to soil compaction and rutting because the road bed
(1) Dipartimento di Gestione dei Sistemi Agrari, Alimentari e Forestali (GESAAF), Università di Firenze. v. S. Bonaventura 13, I-50145 Firenze (Italy); (2) Department of Forest Biomaterials and Technology, Swedish University of Agricultural Sciences, Skogsmarksgränd, Umeå (Sweden)

@ Francesca Giannetti (francesca.giannetti@unifi.it)

Received: Aug 08, 2017 - Accepted: Dec 11, 2017

Citation: Cambi M, Giannetti F, Bottalico F, Travaglini D, Nordfjell T, Chirici G, Marchi E (2018). Estimating machine impact on strip roads via close-range photogrammetry and soil parameters: a case study in central Italy. iForest 11: 148-154. - doi: 10.3832/ifor2590-010 [online 2018-02-07]

Communicated by: Rodolfo Picchio is not naturally compacted and do not have constructed drainage, leading to a reduc tion in soil porosity, water infiltration and gas exchange, as well as increasing soil erosion, water logging and mudflows (Jansson \& Johansson 1998, McFero Grace et al. 2006, Christopher \& Visser 2007).

Most studies concerning soil degradation due to forest operations have examined the physical parameters of soil, such as bulk density, total porosity, macro and micro porosity, shear and penetration resistances, and infiltration capacity (Alakukku et al. 2003, Ampoorter et al. 2007, Jourghophysical parameters of soil are usually determined by means of soil sample collection and analysis, or measured using specific instruments, such as penetrometers and scissometers (Picchio et al. 2012, Venanzi et al. 2016), or by means of manual measurements of cross-sectional and longitudinal profiles on skid trails (Koren et al. 2015). Although these methods have been improved over time (Jourgholami et al. 2014), they are time consuming and costly. Moreover, these methods may affect the study area when repeatedly applied. lami et al. 2014, Marchi et al. 2014). The 
Recently, the field methods used for the analysis of geomorphological processes and quantification of soil impacts have changed, passing from traditional methods (Lotfalian \& Parsakhoo 2009, Bagheri et al. 2013, Koren et al. 2015) to the use of remote sensing and proximal sensing techniques (D'Oleire-Oltmanns et al. 2012, Talbot et al. 2017) in order to analyse the spatial distribution of soil disturbances (Koren et al. 2015, Giannetti et al. 2017). In recent decades, techniques allowing rapid acquisition of high-density topographic data have proliferated (Nadal-Romero et al. 2015). These techniques include terrestrial laser scanners (TLS - Vericat et al. 2014, Castillo et al. 2015) and photogrammetry techniques (Castillo et al. 2015, Kaiser et al. 2014), which are used, for example, for the analysis of soil erosion (Michetti et al. 2015, Nadal-Romero et al. 2015). Such techniques make it possible to generate digital elevation models that accurately reproduce topographic surfaces (Vericat et al. 2014, Pierzchala et al. 2014, 2016, Nadal-Romero et al. 2015). Various methods have been proposed to measure soil surface microtopography (Heng et al. 2010), and their relative strengths and weaknesses have been discussed in recent comparative studies (Jester \& Klik 2005, Aguilar et al. 2009). Although the use of close-range photogrammetry in mapping soil surface structure was demonstrated more than 20 years ago (Warner 1995), the advent of structure-from-motion (SfM) photogrammetry (James \& Robson 2012) has generated an improvement in topographic methods, due to its better accessibility to a wider variety of users, low cost, and increased automatization of routines and workflow (Nadal-Romero et al. 2015). The advantages introduced by SFM in geosciences have been demonstrated by James \& Robson (2012), and the reconstruction of high-resolution surface models (Turner et al. 2012) has opened new possibilities of application in geoscience analysis (Castillo et al. 2015), forestry (Pierzchala et al. 2014, Pierzchala et al. 2016) and agriculture (Nouwakpo \& Huang 2012).

The objective of this study was to investigate the usefulness of SfM photogrammetry in association with traditional methods for assessing soil disturbance in forest operations. The effects of forest operations on soil were considered for two types of forest machines, forwarder and skidder. The specific objectives of the study were: (i) to evaluate multitemporal analysis based on the use of image-based high-reso-

Tab. 1 - Details for camera and sensors used in the current study.

\begin{tabular}{lc}
\hline Camera model & Nikon D90 \\
Image resolution (pixel) & $4288 \times 2848$ \\
Focal length $(\mathrm{mm})$ & 22 \\
Pixel size $(\mathrm{mm})$ & $1 \times 1$ \\
\hline
\end{tabular}

lution ground surface models generated through the use of SfM photogrammetry workflow as an instrument to determine rutting and bulges caused by forest operations along all trail surfaces; (ii) to assess soil compaction with traditional techniques.

\section{Materials and methods}

\section{Study area}

The study was conducted in central Italy, in the Biogenetic reserve of Vallombrosa, which is in the municipality of Reggello (Florence Province). The study area covers 5.78 ha between 920 and $980 \mathrm{~m}$ a.s.l. and is characterised by moderate steep terrain (mean slope $=30 \%$ ). The forest is characterised by an even-aged silver fir (Abies alba Mill.) plantation that was completely destroyed by a windstorm on the $5^{\text {th }}$ of March, 2015 (Pirotti et al. 2016, Chirici et al. 2017). The climate is temperate-humid with Mediterranean-type rainfall (summer minimum) and a mean annual temperature of 9.7 ${ }^{\circ} \mathrm{C}$. From 2009-2013, the mean annual precipitation was $1337 \mathrm{~mm}$, with an average of $71.2 \mathrm{~mm}$ in June-August (Bottalico et al. 2014). Soil developed on sedimentary rocks of the boulder formation of Chianti, which are comprised of sandstone with thin layers of siltstone and rarely marl. Soil can be classified as Umbrepts and Umbric Dytrochrepts, based on the USDA Soil Taxonomy (1990). This study was carried out during salvage harvesting of damaged trees.

\section{Forest machines}

Two forestry machines were used in our study. The first was a forwarder John Deere JD1110 D with an empty mass of 17.5 tons (121 kW), which was equipped with 8wheel Nokian Forest Rider 700/50 × 26.5 tires inflated at $51 \mathrm{kPa}$. The second machine was a skidder John Deere $548 \mathrm{H}$ with an empty mass of 11 tons ( $96 \mathrm{~kW}$ ), equipped with 4-wheel Nokian Forest Rider 622/32 × 24.5 tires with chains, inflated to $68 \mathrm{kPa}$.

\section{Experimental design}

Before logging, two $25 \times 3.5 \mathrm{~m}$ plots were randomly selected in the study area along the trails designed for timber extraction; the first plot in the trail designated to be trafficked by the forwarder (henceforth: $\mathrm{FT}$, forwarder trail), and the second in the trail to be trafficked by the skidder (ST, skidder trail). The mean slopes of the FT and ST plots were $25 \%$ and $20 \%$, respectively.

Data collection was carried out at three time points: before forest logging (Time 1), considered as control data; seven working days after the beginning of logging (Time 2); and 13 working days after the beginning of logging (i.e., the day after the end of wood extraction - Time 3). The collected data were compared, taking into account the difference between: (i) periods 1 and 2 $\left(\Delta_{12}\right)$; (ii) periods 2 and $3\left(\Delta_{23}\right)$; and (iii) peri- ods 1 and $3\left(\Delta_{13}\right)$. The forwarder transported logs up to $6 \mathrm{~m}$ in length and the skidder transported whole un-delimbed trees. Extraction was carried out in uphill direction for both machines.

\section{Data collection}

\section{Photogrammetry data}

Image acquisition. Pictures in FT and ST plots were collected using a consumer reflex camera (Tab. 1) mounted on a tripod $1.90 \mathrm{~m}$ in height. The image points were located at the corner of a rectangular network (Fig. 1). Images were acquired in nadir angle with an overlap and a side lap of $95 \%$ every 30 centimetre. The area covered by the images was greater than that of the plots, for a total of $180 \mathrm{~m}^{2}$, in order to have a robust model of the trails. A total of 350 images were acquired for each trail in each period. The image acquisition was done in 20 minutes for each trial in each period.

Ground control points. Ground control points (GCPs) were identified for image geolocation. Two types were measured in each trial: (i) six GCPs to georeference each model; and (ii) four permanent GCPs outside the trails that were used to co-register the three models obtained (Fig. 1). The X, Y and $Z$ coordinates of each GCP were measured with a total station Leica TCA $1800^{\circledR}$ (Leica Geosystems AG, Heerbrugg, Switzerland). The GCPs were translocated into the geographic coordinates system (UTM32NWGS84) using the coordinates of one fixed control point measured by a GPS receiver (Trimble JUNO ${ }^{\circledast}$ Series 3B, GeoMobile Innovations, Corvallis, OR, USA). The permanent GCPs were represented in the field by a survey geodetic marker and were protected from the passage of forest machines.

Photogrammetry process. The SfM technique was applied to obtain a 3D georeferenced point cloud from which a digital surface model (DSM) was derived. Data were processed using the Agisoft PhotoScan ${ }^{\oplus}$ Structure for Motion (SfM) photogrammetric software package (http://www.agi soft. com/), which has been successfully used in different analyses (Verhoeven et al. 2012, Javernick et al. 2014, Woodget et al. 2014, Puliti et al. 2015). The workflow was comprised of the following steps: (i) image import; (ii) image alignment; (iii) georeferencing; (iv) optimisation of image alignment; ( $v$ ) creation of the point cloud; and (vi) generation of the DSM. After the alignment, all photos were oriented, and the raw point cloud was georeferenced. The GCPs were then used to optimise the alignment of camera positions and the orientation of the data, which allowed for better accuracy and reconstruction results. Based on the estimated camera positions and GCPs, the depth information for each image was calculated using Agisoft Photo$\mathrm{Scan}^{\oplus}$, to be combined into a single dense point cloud dataset. The georeferentiation 
errors calculated by the software along the $x, y$ and $z$ coordinates for each 3D point cloud models obtained via the structurefrom-motion methodology (i.e., FT1, FT2, $\mathrm{FT}_{3}, \mathrm{SK}_{1}, \mathrm{SK}_{2}, \mathrm{SK}_{3}$ ) for $\mathrm{X}, \mathrm{Y}$ and $\mathrm{Z}$ coordinate was $<1 \mathrm{~cm}$.

Co-registration of model and difference calculation. The three-dense point clouds obtained by SfM workflow (FT1, FT2, FT3 and $\mathrm{SK}_{1}, \mathrm{SK}_{2}, \mathrm{SK}_{3}$ ) were co-registered using the four permanent GCPs outside the trail area by means of a point-based alignment the open source freeware CloudCompare ver. 2 (http://cloudcompare.org/). This tool coarsely aligns two-point clouds using the " 4 points Congruent Sets For Robust Registration" algorithm (Aiger et al. 2008). After the co-registration process, the point clouds were rasterised with the rasterisation tools present in CloudCompare to create very high-resolution digital terrain models (DTMs) of each period for FT (FT-DTM1, FT-DTM2, FT-DTM3) and SK (SK-DTM1, SKDTM2, SK-DTM3), with pixels of $0.1 \times 0.1$ $\mathrm{cm}$. For each raster cell, the average elevation of the points in the pixel area was found and recorded in the cell.

The digital terrain models before logging (DTM1), half-way through logging operations (DTM2) and after logging operations (DTM3) were compared using map algebra tools, and differences in terrain elevation $(\Delta z)$ after forest operations were computed as $\Delta_{12}=$ DTM1-DTM2, $\Delta_{23}=$ DTM2DTM3 and $\Delta_{13}=$ DTM1-DTM3. Pixels with $\Delta$ $<0$ were considered to be in ruts and pixels with $\Delta>0$ were considered to be in bulges along the surface of the two trails. The average, minimum and standard deviation were computed for $\Delta<0$ pixels, whereas the average, maximum and standard deviation were computed for $\Delta>0$ pixels for $\Delta_{12}$, $\Delta_{23}$ and $\Delta_{13}$

\section{Physical parameters}

Thirty soil samples were collected at Times 1, 2 and 3, for a total of $90(30 \times 3)$ samples (Fig. 2). Samples were extracted from the topsoil layer using a rigid metallic cylinder (8.5- $\mathrm{cm}$ height and 5.0-cm inner diameter) after litter removal and used for determining bulk density. Penetration and shear resistance were measured in triplicate close to each sampling point, using a TONS/FT2 penetrometer (Eijkelkamp, Giesbeek, Netherlands) and a GEONOR 72412 scissometer (Geonor, Augusta, NJ, USA), respectively. Soil samples were taken along the tire tracks of the two machines (Fig. 1). All soil samples were weighed in the laboratory before ("moist weight") and after oven drying at $105^{\circ} \mathrm{C}$ to a constant weight ("dry weight"). Bulk density was determined as the ratio between soil sample dry weight and volume. Soil porosity (PO) was determined using the following equation (eqn. 1):

$$
P O=\frac{D p-B D}{D p} \cdot 100
$$

where $D p$ is the particle density measured

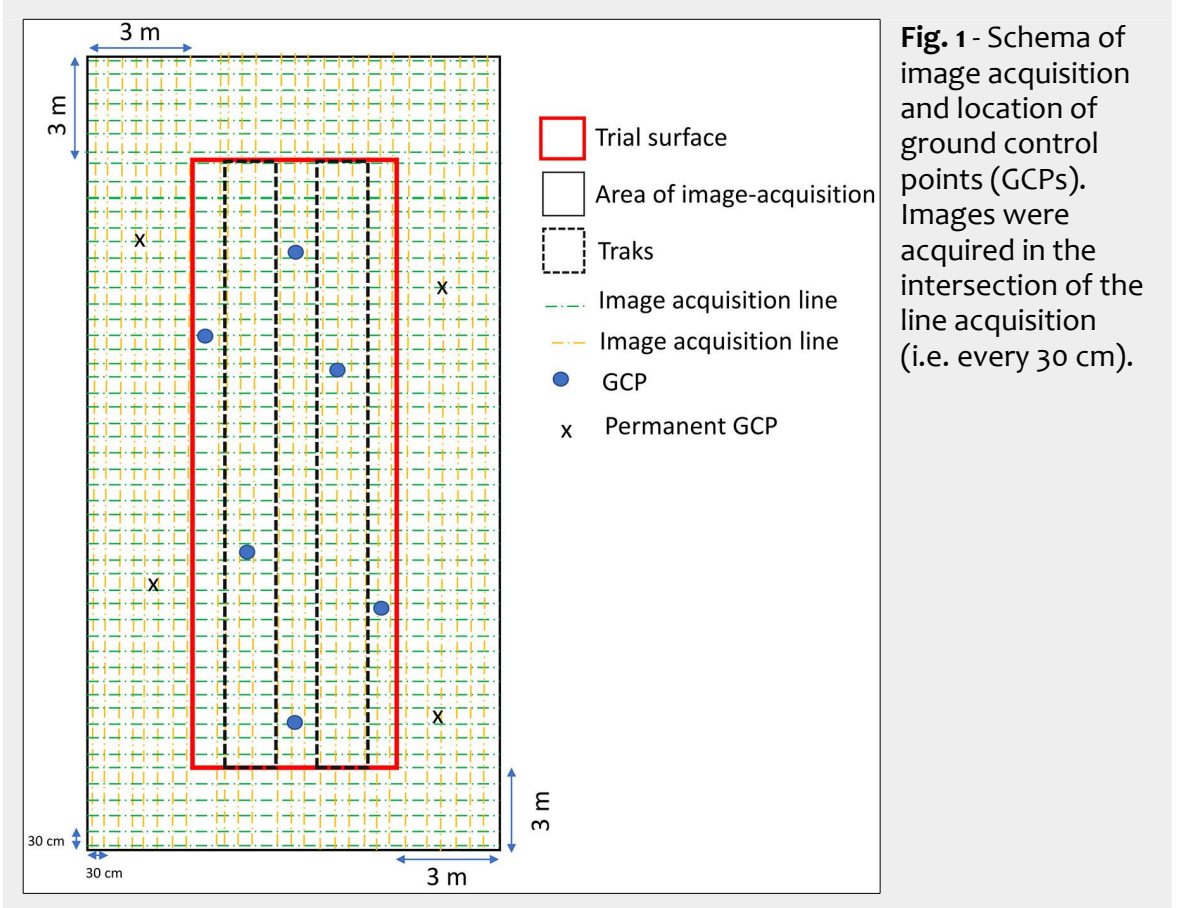

by a pycnometer (Multipycnometer, Quantachrome, Boynton Beach, FL, USA) on the same soil samples used to determine the bulk density (BD).

\section{Statistical analysis}

Statistical analyses were carried out using the software package STATISTICA ${ }^{\circledR}$ ver. 7.1 (StatSoft, Tulsa, OK, USA). All data were checked for normality (Kolmogorov-Smirnov test) and homogeneity of variance (Levene's test) before the analysis. MANOVA and post-hoc Tukey's HSD test were applied to physical parameters to assess the statistical differences among times (1-2, 2-3 and 1-3) and between machines (FT and $\mathrm{ST})$.

A t-test was applied to the values of changes in ground surface level $(\Delta<0=$ ruts/soil removal and $\Delta>0=$ bulges/soil in- crease) between $\Delta_{12}$ and $\Delta_{23}$ in order to assess statistically significant differences between both times ( 2 and 3 ) and machines (FT and ST).

\section{Results}

The high-resolution surface models were derived by SfM workflow. Changes in soil surface level after logging are indicated with different colours in Fig. 3 and Fig. 4.

Significant differences $(p<0.05)$ between FT and ST were found when comparing ruts/soil removal and bulges/soil increases at both time intervals $\Delta_{12}$ and $\Delta_{23}$ (Tab. 2). Specifically, significant differences in bulge height/soil increase were recorded between vehicles at both time intervals $\left(\Delta_{12}\right.$ and $\Delta_{23}$ ), whereas rut depth/soil removal showed significant differences only in the first period $\left(\Delta_{12}\right)$. FT treatment showed

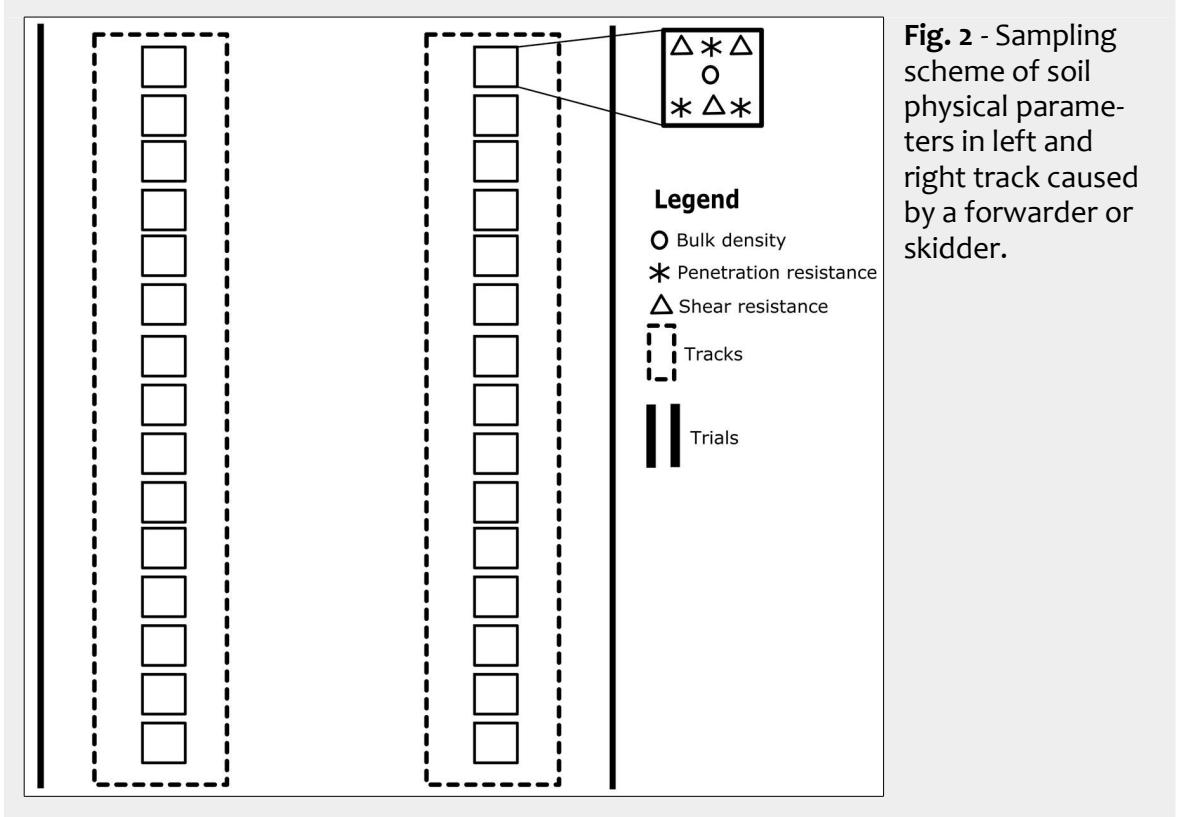


Tab. 2 - Quantification of the ground surface variation produced by forwarder trails (FT) and skidder trails (ST) after different time periods, calculated considering all $\Delta<0$ pixels as rutting and all $\Delta>0$ pixels as bulges. Upper-case letters represent significant differences between FT and ST at the same period, whereas lower-case letters represent significant differences between different periods for the same vehicle ( $t$-test). (STD): standard deviation; $\left({ }^{*}\right): \mathrm{p}<0.05 ;(* *): \mathrm{p}<0.001$.

\begin{tabular}{cccccc}
\hline & & \multicolumn{4}{c}{ Ground Surface Variation } \\
\cline { 3 - 6 } Trail & $\begin{array}{c}\text { Time } \\
\text { interval }\end{array}$ & \multicolumn{2}{c}{ Rut depth/soil removal $(\Delta<0)$} & \multicolumn{2}{c}{ Bulge/soil increase $(\Delta>0)$} \\
\cline { 3 - 6 } & & $\begin{array}{c}\text { Minimum } \\
(\mathbf{c m})\end{array}$ & $\begin{array}{c}\text { Mean } \pm \text { STD } \\
(\mathbf{c m})\end{array}$ & $\begin{array}{c}\text { Maximum } \\
(\mathbf{c m})\end{array}$ & $\begin{array}{c}\text { Mean } \pm \text { STD } \\
(\mathbf{c m})\end{array}$ \\
\hline FT & $\Delta_{12}$ & -36.5 & $-17.9 \pm 12.1^{\mathrm{a}^{*} \mathrm{~A}^{*}}$ & 13.5 & $9.5 \pm 2.5^{\mathrm{a}^{*} \mathrm{~A}^{*}}$ \\
& $\Delta_{23}$ & -12.3 & $-4.7 \pm 3.6^{\mathrm{b}^{*} \mathrm{~A}}$ & 5.3 & $3.7 \pm 2.1^{\mathrm{b}^{*} \mathrm{~A}^{*}}$ \\
& $\Delta_{13}$ & -39.5 & $-12.3 \pm 8.2$ & 15.6 & $9.8 \pm 2.6^{6^{*}}$ \\
\hline & $\Delta_{12}$ & -21.4 & $-8.9 \pm 2.9^{\mathrm{a}^{* *} \mathrm{~B}^{*}}$ & 5.0 & $4.1 \pm 1.0^{\mathrm{a}^{*} \mathrm{~B}^{*}}$ \\
& $\Delta_{23}$ & -10.7 & $-4.8 \pm 2.5^{\mathrm{b}^{* *} \mathrm{~A}}$ & 1.4 & $1.1 \pm 0.8^{\mathrm{b}^{*} \mathrm{~B}^{*}}$ \\
& $\Delta_{13}$ & -15.6 & $-6.1 \pm 5.3$ & 3.5 & $2.2 \pm 1.6$ \\
\hline
\end{tabular}

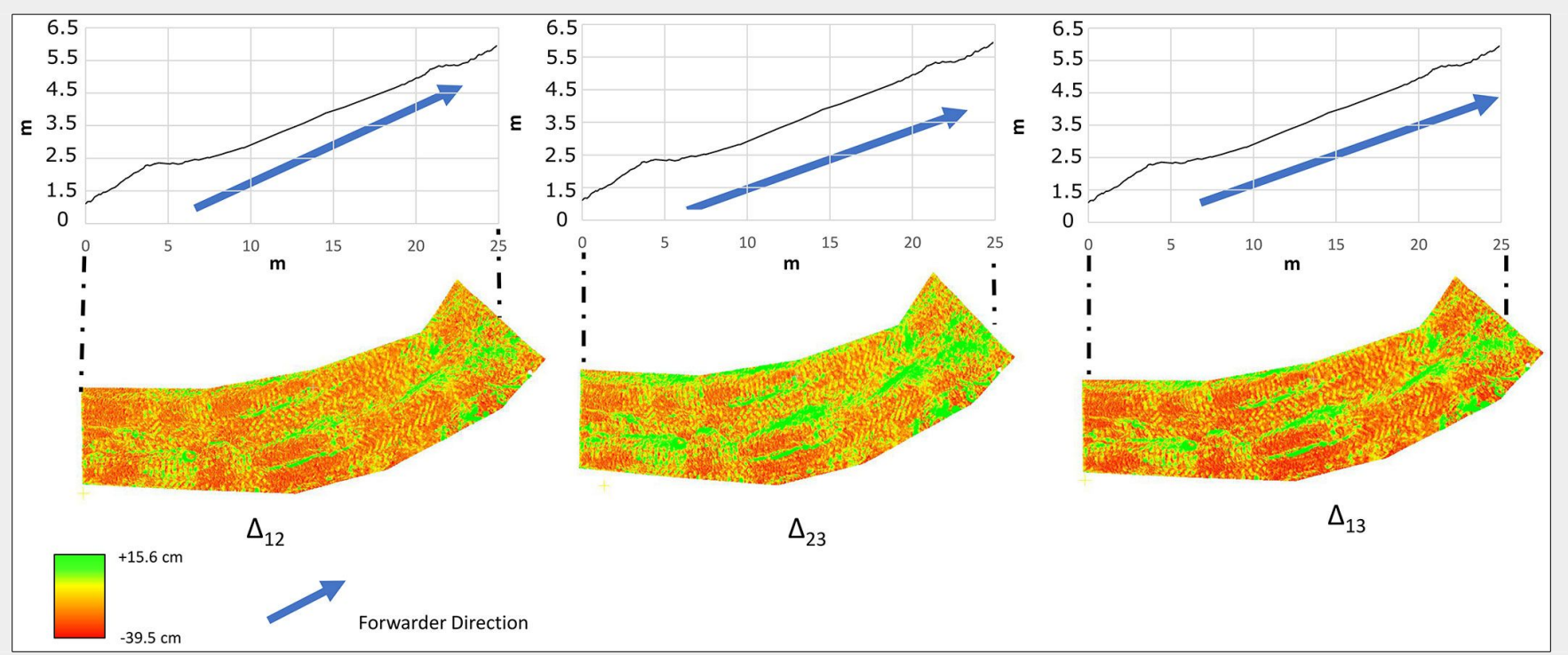

Fig. 3 - Effects on soil produced by forwarder passes between Time 1 and Time $2\left(\Delta_{12}\right)$, Time 2 and Time $3\left(\Delta_{23}\right)$, and between Time 1 and Time $3\left(\Delta_{13}\right)$.

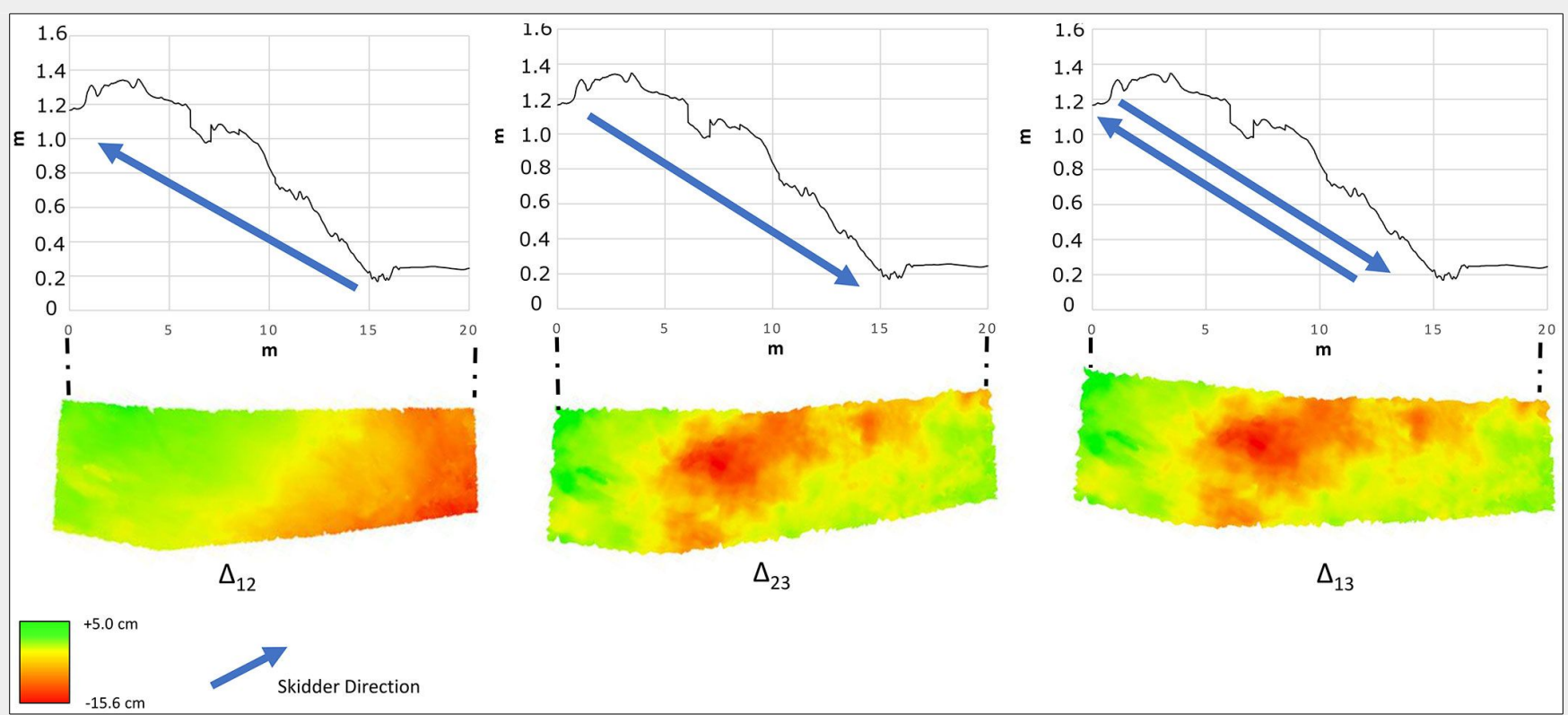

Fig. 4 - Effects on soil produced by skidder passes between Time 1 and Time $2\left(\Delta_{12}\right)$, Time 2 and Time $3\left(\Delta_{23}\right)$, and between Time 1 and Time $3\left(\Delta_{13}\right)$. 
Tab. 3 - Results of MANOVA (mean \pm standard deviation) to evaluate differences in soil parameters between trails used by different logging vehicles (Wilks test's $F=42.33, p<0.001$ ). Different lowercase letters indicate significant differences between Time 1 , Time 2 and Time 3 after Tukey's HSD tests $(\mathrm{p}<0.05, \mathrm{~N}=90)$. Different uppercase letters indicate significant differences between FT and ST at the same time after Tukey's HSD tests $(\mathrm{p}<0.05, \mathrm{~N}=60)$. (FT): forwarder trail; (ST): skidder trail.

\begin{tabular}{|c|c|c|c|c|c|c|}
\hline Trail & Time & $\begin{array}{c}\text { Soil moisture } \\
(\%)\end{array}$ & $\begin{array}{l}\text { Bulk density } \\
\left(\mathrm{g} \mathrm{cm}^{-3}\right)\end{array}$ & $\begin{array}{l}\text { Porosity } \\
\text { (\%) }\end{array}$ & $\begin{array}{c}\text { Shear resistance } \\
(\mathrm{kPa})\end{array}$ & $\begin{array}{l}\text { Penetration } \\
\text { resistance } \\
(\mathrm{MPa})\end{array}$ \\
\hline \multirow[t]{3}{*}{$\mathrm{FT}$} & 1 & $19.38 \pm 4.86^{\mathrm{aA}}$ & $0.81 \pm 0.07^{\mathrm{aA}}$ & $66.28 \pm 6.55^{\mathrm{aA}}$ & $68.02 \pm 2.54^{\mathrm{aA}}$ & $0.35 \pm 0.43^{\mathrm{aA}}$ \\
\hline & 2 & $11.09 \pm 1.55^{\mathrm{bA}}$ & $1.69 \pm 0.24^{\mathrm{bA}}$ & $35.89 \pm 9.45^{\mathrm{bA}}$ & $77.81 \pm 7.92^{\mathrm{bA}}$ & $0.46 \pm 0.34^{\mathrm{bA}}$ \\
\hline & 3 & $11.13 \pm 1.56^{\mathrm{bA}}$ & $1.71 \pm 0.25^{\mathrm{bA}}$ & $35.88 \pm 9.44^{\mathrm{bA}}$ & $77.80 \pm 7.93 \mathrm{bA}$ & $0.45 \pm 0.35^{\mathrm{bA}}$ \\
\hline \multirow[t]{3}{*}{ ST } & 1 & $19.37 \pm 4.86^{\mathrm{aA}}$ & $0.82 \pm 0.07^{\mathrm{aA}}$ & $66.26 \pm 6.55^{\mathrm{aA}}$ & $68.04 \pm 2.54^{\mathrm{aA}}$ & $0.33 \pm 0.43^{\mathrm{aA}}$ \\
\hline & 2 & $19.24 \pm 4.70^{\mathrm{aB}}$ & $1.06 \pm 0.16^{\mathrm{bB}}$ & $61.03 \pm 6.59^{\mathrm{bB}}$ & $72.40 \pm 8.20 \mathrm{bB}$ & $0.42 \pm 0.47^{\mathrm{BB}}$ \\
\hline & 3 & $19.26 \pm 4.72^{\mathrm{aB}}$ & $1.07 \pm 0.18^{\mathrm{bB}}$ & $60.54 \pm 6.62^{\mathrm{bB}}$ & $72.33 \pm 8.23$ & $0.41 \pm 0.51$ \\
\hline
\end{tabular}

logging, from Time 2 to Time 3, soil was further displaced due to the increasing number of passes. Specifically, a certain quantity of soil was removed on ST at the beginning of the steeper part of the trail and replaced in the flat area at the end of the plot in the skidding direction (Fig. 4).

On FT, soil moisture, bulk density, porosity, and shear and penetration resistance were significantly higher after logging operations (at Time 2 and Time 3 ) as compared with control (Time 1). The same parameters did not show significant differences between Time 2 and Time 3, thus suggesting that most of the compaction was reached within the first several logging days. Similar results were obtained on ST, except that soil moisture did not show differences between Time 1 and Time 2 (Tab. 3).

\section{Discussion}

At present, the physical parameters of soil are generally assumed to be the most useful for the assessment of impacts on soil due to vehicle traffic (Cambi et al. 2015). This is why we used bulk density, penetration resistance, shear resistance and soil porosity for measuring soil compaction. In agreement with the results of previous studies (Wang et al. 1997, Williamson \& Neilsen 2000, Wallbrink et al. 2002, Han et al. 2009), our findings showed that the investigated physical parameters of soil were significantly affected mainly by the first vehicle passes (comparison between Time 1 and Time 2). Further machine passes slightly increased or did not affect soil physical parameters.

Similar results concerning the impact of forwarder extraction on soil were recorded for the same parameters during timber extraction in the Italian Alps by Cambi et al. (2016). Other studies, however, have found opposing results. Gondard et al. (2003) assessed the impacts of clear-cutting in Aleppo pine (Pinus halepensis) forests in southern France using both forwarders and skidders, observing deep disturbance (i.e., "topsoil removed, subsoil exposed", according to methods and classification proposed by McMahon 1995) only when a skidder was used and no ruts. Similar re- sults were reported by Deconchat (2001) in mixed oak coppices (Quercus robur, Q. petraea and Q. pubescens) in southern France under an Oceanic climate. In this study, the observed greater soil disturbance was due to skidders rather than forwarders, though skidders were responsible for less than $1 \%$ of ruts. However, it should be considered that both the aforementioned studies were based on methods developed for assessing soil surface disturbance by the simple observation of soil conditions after logging, thereby less visible effects, such as soil compaction, cannot immediately detected (Spinelli et al. 2010). Moreover, it is worth noting that the first study was carried out under dry soil conditions, when soil is highly resistant to compaction and only the scratching action of dragged logs may have any effect.

Despite our results highlighted a larger soil disturbance caused by forwarders than skidders, we cannot draw any general conclusions about differences between the two machines. In fact, neither data about the number of machine passes nor the wood volumes transported over each trial area were available in this study. Without this information any general conclusion could be misleading. The most common planning of harvesting operations gives as a result that skidders are driven in a more dense extraction trail network than what forwarders do (Han et al. 2009). This could be interpreted as the result of different soil disturbance at the harvesting site, which is more concentrated to a fewer extraction trails using forwarders and more spread using skidders.

Soil compaction also depends on machine size, weight and the pressure exerted on soil (Jansson \& Johansson 1998, McNabb et al. 2001, Bygdén et al. 2004, Eliasson 2005, Marchi et al. 2014). To measure rutting, manual measurements of cross-sectional and longitudinal profiles are commonly applied (Koren et al. 2015). These methods are used for determining the rut depth at intervals along the trail and may be used to obtain a rough estimate of the volume of soil displaced. Our study indicated that the use of SfM photogrammetry may be very useful for the precise mea- surement of rutting and soil displacement. The analysis of differences in ground surface shape through the use of image-based models derived by SfM may offer detailed information about changes in the characteristics of ruts along the trail and may highlight soil displacement in all directions (e.g., from the tracks to the trail's centre and sides, along the trail). Our results showed that in the first time interval, the FT caused deeper ruts and higher bulges than ST (Tab. 3). In the digital terrain model for FT obtained using SfM photogrammetry, ruts were clearly identifiable, whereas soil displacement along the trail was not detectable. In contrast, ruts were not visible on ST, but soil displacement along the trail was clearly detectable. These difference between FT and ST were likely due to the different types of timber extraction. In fact, rutting is caused by machine wheels both in FT and ST, but in ST the passing of the top end of the dragged logs (Wood et al. 2003) may change the impacts on soil in two ways: (i) the top ends of the dragged logs reshape the ground after the skidder passes, hiding the rut left by the wheels; (ii) the top ends of the dragged logs displace a certain quantity of soil in the dragging direction during each extraction trip. The latter effect may be particularly intense close to slope changes, because the heads of the logs scratch and displace the soil (Williamson \& Neilsen 2000, Heninger et al. 2002, Horn et al. 2007, Agherkakli et al. 2010). Soil compaction and soil crumbling and displacement may result in increased water runoff and soil erosion (Williamson \& Neilsen 2000, Cambi et al. 2015, Venanzi et al. 2016), with a consequent loss of fertile soil (Venanzi et al. 2016).

Forest soil is extremely fragile in physical terms and the improvement of methods for investigating the effects of soil disturbance is very important (Picchio et al. 2012). With the use of image-based models derived from SfM photogrammetry, the quantification of soil displacement is highly improved in comparison to traditional sampling methods. The use of image-based models allows a new approach to the quantification of soil disturbance, improving the analysis of soil displacement due to 
logging, comparable with results obtained by point cloud derived by TLS (Koren et al. 2015). The use of a consumer reflex camera combined with the use of SfM software, however, can produce accuracy models at low cost, with respect to the use of TLS. The use of this methodology (Pierzchala et al. 2014, 2016, Koren et al. 2015) can produce information along the entire trail, not only at the sampling points. This information is very important for forest managers, as it allows for monitoring of soil ecosystems after forest operations and planning of soil recovery practices (Pinard et al. 2000).

\section{Conclusions}

The main aim of this study was to describe the effects of logging on both the physical properties of soil and the depth of ruts, through manual measurements in the field and photogrammetry analysis. Our findings highlighted how the use of both manual sampling and image-based models derived via SfM photogrammetry may be very useful to assess the impact of forest operations on soil. Both methods showed significant impacts on soil caused by two different forest machines.

Image-based models proved to be useful for determining distribution and types of disturbance, while the physical parameters of soils investigated in this study may be useful in determining local changes in soil characteristics. Our results showed that image-based models derived through SfM photogrammetric workflow can be useful tools to evaluate soil displacement caused by forest machines, improving monitoring and management of impacts upon soil and giving continuous soil displacement measures along the entire trail surface.

\section{Acknowledgements}

The authors would like to thank the Territorial Office for Biodiversity (Carabinieri Forestale) of Vallombrosa (Firenze, Italy) for its support in the research study and Dr. Giovanni Galipò for his help with the field survey. A special thank to Ms. Ilaria Zorzi for her help with the fieldwork.

\section{References}

Agherkakli B, Najafi A, Sadeghi S (2010). Ground based operation effects on soil disturbance by steel tracked skidder in a steep slope of forest. Journal of Forest Science 56: 278-284. [online] URL: http://www.agriculturejournals.cz/public Files/22356.pdf

Aguilar MA, Aguilar RJ, Negreiros J (2009). Offthe-shelf laser scanning and close-range digital photogrammetry for measuring agricultural soils microrelief. Biosystems Engineering 103: 504-517. - doi: 10.1016/j.biosystemseng.2009.02. 010

Aiger D, Mitra NJ, Cohen-Or D (2008). Fourpoints congruent sets for robust surface registration. ACM Transactions on Graphics, Proc. SIGGRAPH 27 (3): 1-10.

Alakukku L, Weisskopf P, Chamen WC, Tijink FG, Van Der Linden J, Pires S, Sommer C, Spoor G
(2003). Prevention strategies for field traffic induced subsoil compaction: a review. Soil and Tillage Research 73 145-160. - doi: 10.1016/S01671987(03)00107-7

Ampoorter E, Goris R, Cornelis WM, Verheyen K (2007). Impact of mechanized logging on compaction status of sandy forest soils. Forest Ecology and Management 241: 162-174. - doi: 10.1016 /j.foreco.2007.01.019

Bagheri I, Naghdi R, Jalali AM (2013). Evaluation of factors affecting soil erosion along skid trails (case study; Shafarood Forest, Northern Iran). Caspian Journal of Environmental Science 11: 151-16o. [online] URL: http://cjes.guilan.ac.ir/arti cle_1121_11.html

Bottalico F, Travaglini D, Fiorentini S, Lisa C, Nocentini S (2014). Stand dynamics and natural regeneration in silver fir (Abies alba Mill.) plantations after traditional rotation age. iForest 7: 313-323. - doi: 10.3832/iforog85-007

Bygdén G, Eliasson L, Wästerlund I (2004). Rut depth, soil compaction and rolling resistance when using bogie tracks. Journal of Terramechanics 40: 179-190. - doi: 10.1016/j.jterra.2003. 12.001

Cambi M, Certini G, Neri F, Marchi E (2015). The impact of heavy traffic on forest soils: a review. Forest Ecology and Management 338: 124-138. doi: 10.1016/j.foreco.2014.11.022

Cambi M, Grigolato S, Neri F, Picchio R, Marchi E (2016). Effects of forwarder operation on soil physical characteristics: a case study in the Italian Alps. Croatian Journal of Forest Engineering 37 (2): 233-239. [online] URL: http://hrcak.srce. hr/index.php?show=clanak\&id_clanak_jezik=25 6584\&lang=en

Castillo R, James CM, Redel-Macías MD, Pérez R, Gómez JA (2015). SF3M software: 3-D photoreconstruction for non-expert users and its application to a gully network. Soil 1: 583-594. doi: 10.5194/soil-1-583-2015

Chirici G, Bottalico F, Giannetti F, Rossi P, Del Perugia B, Travaglini D, Nocentini S, Ruedlinger EHK, Marchi E, Foderi F, Fioravanti M, Fattorini L, Guariglia A, Ciancio O, McRoberts LR, Naesset E, Corona P, Gozzini B (2018). Assessing forest windthrow damage using single-date, postevent airborne laser scanning data. Forestry: An International Journal of Forest Research 91 (1): 27-37. - doi: 10.1093/forestry/cpx029

Christopher EA, Visser R (2007). Methodology for evaluating post harvest erosion risk for the protection of water quality. New Zealand Journal of Forestry 2007 52: 20-25. [online] URL: http://nzjf.org.nz/free_issues/NZJF52_2_2007/0 9BD57F4-FF32-4095-A22E-50579B1F1CE4.pdf

Deconchat $M$ (2001). Effects of logging techniques on the soil surface. Annals of Forest Sciences 58: 653-661. - doi: 10.1051/forest:2001152

D’Oleire-Oltmanns S, Marzolff I, Peter K, Ries J (2012). Unmanned Aerial Vehicle (UAV) for monitoring soil erosion in Morocco. Remote Sensing 4: 3390-3416. - doi: 10.3390/rs4113390 Eliasson $L$ (2005). Effects of forwarder tyre pressure on rut formation and soil compaction. Silva Fennica 39: 549-557. - doi: 10.14214/sf.366 Giannetti F, Chirici G, Travaglini D, Bottalico F, Marchi E, Cambi M (2017). Assessment of soil disturbance caused by forest operations by means of portable laser scanner and soil physical parameters. Soil Science Society of America
Journal 81 (6): 1577. - doi: 10.2136/sssaj2017.02. 0051

Gomez A, Powers RF, Singer MJ, Horwath WR (2002). Soil compaction effects on growth of young ponderosa pine following litter removal in California's Sierra Nevada. Soil Science Society of America Journal 66: 1334-1343. - doi: 10.2136/sssaj2002.1334

Gondard H, Romane F, Aronson J, Shater Z (2003). Impact of soil surface disturbances on functional group diversity after clear-cutting in Aleppo pine (Pinus halepensis) forests in southern France. Forest Ecology and Management 180: 165-174. - doi: 10.1016/S0378-1127(02)005972

Han SK, Han HS, Page-Dumroese D, Johnson LR (2009). Soil compaction associated with cut-tolength and whole-tree harvesting of a coniferous forest. Canadian Journal of Forest Research 39: 976-989. - doi: 10.1139/Xo9-027

Heng BCP, Chandler JM, Armstrong A (2010). Applying close range digital photogrammetry in soil erosion studies. The Photogrammetric Record 25: 240-265. - doi: 10.1111/j.1477-9730.20 10.00584.x

Heninger R, Scott W, Dobkowski A, Miller R, Anderson H, Duke S (2002). Soil disturbance and 10-year growth response of coast Douglas-fir on non-tilled and tilled skid trails in the Oregon Cascades. Canadian Journal of Forest Research 32: 233-246. - doi: 10.1139/x01-195

Horn R, Vossbrink J, Peth S, Becker S (2007). Impact of modern forest vehicles on soil physical properties. Forest Ecology and Management 248 (1-2): 56-63. - doi: 10.1016/j.foreco.2007.02. 037

James MR, Robson S (2012). Straightforward reconstruction of $3 \mathrm{D}$ surfaces and topography with a camera: accuracy and geoscience application. Journal of Geophysical Research 117: F03017. - doi: 10.1029/2011JF002289

Jamshidi R, Jaeger D, Raafatnia N, Tabari M (2008). Influence of two ground-based skidding systems on soil compaction under different slope and gradient conditions. International Journal of Engineering Science 19: 9-16. [online] URL: http://www.tandfonline.com/doi/ abs/10.1080/14942119.2008.10702554

Jansson KJ, Johansson J (1998). Soil changes after traffic with a tracked and wheeled forest machine: a case study on a silt loam in Sweden. Forestry 71: 57-66. - doi: 10.1093/forestry/71.1.57 Javernick L, Brasington B, Caruso B (2014). Modeling the topography of shallow braided rivers using structure-from-motion photogrammetry. Geomorphology 213: 166-182. - doi: 10.1016/j.geo morph.2014.01.006

Jester W, Klik A (2005). Soil surface roughness measurement - methods, applicability, and surface representation. Catena 64 (2-3): 174-192. doi: 10.1016/j.catena.2005.08.005

Jourgholami M, Soltanpour S, Etehadi Abari M, Zenner EK (2014). Influence of slope on physical soil disturbance due to farm tractor forwarding in a Hyrcanian forest of northern Iran. iForest 7: 342-348. - doi: 10.3832/ifor1141-007 Kaiser A, Neugirg F, Rock G, Müller C, Haas F, Ries J, Schmidt J (2014). Small-scale surface reconstruction and volume calculation of soil erosion in complex Moroccan gully morphology using structure from motion. Remote Sensing 6 
(8): 7050-7080. - doi: $10.3390 /$ rs6087050 Koren M, Slančík M, Suchomel J, Dubina J (2015). Use of terrestrial laser scanning to evaluate the spatial distribution of soil disturbance by skidding operations. iForest 8: 386-393. - doi: 10.383 2/ifor1165-007

Lotfalian M, Parsakhoo A (2009). Investigation of forest soil disturbance caused by rubbertired skidder traffic. International Journal of Natural and Engineering Sciences 3: 79-82.

Marchi E, Picchio R, Spinelli R, Verani S, Venanzi $R$, Certini G (2014). Environmental impact assessment of different logging methods in pine forests thinning. Ecological Engineering 70: 429-436. - doi: 10.1016/j.ecoleng.2014.06.019 McFero Grace J, Skaggs RW, Cassel DK (2006). Soil physical changes associated with forest harvesting operations on an organic soil. Soil Science Society of America Journal 70: 503-509. - doi: 10.2136/sssaj2005.0154

McMahon S (1995). A survey method for assessing site disturbance. Project Report no. 54, Logging Industry Research Organisation, New Zealand, pp. 16.

McNabb DH, Startsev AD, Nguyen H (2001). Soil wetness and traffic level effects on bulk density and air-filled porosity of compacted boreal forest soils. Soil Science Society of America Journal 65: 1238-1247. - doi: 10.2136/sssaj2001. $6541238 x$

Michetti N, Chandler JH, Lane SN (2015). Investigating the geomorphological potential of freely available and accessible structure-from-motion photogrammetry using a smartphone. Earth Surface Processes and Landforms 40: 473-486. - doi: 10.1002/esp.3648

Nadal-Romero E, Revuelto J, Errea P, López-Moreno JI (2015). The application of terrestrial laser scanner and SfM photogrammetry in measuring erosion and deposition processes in two opposite slopes in a humid badlands area (central Spanish Pyrenees). Soil 1: 561-573. - doi: 10.5194/soil-1-561-2015

Nouwakpo SK, Huang C (2012). A simplified close-range photogrammetric technique for soil erosion assessment. Soil Science Society of America Journal 76: 70-84. - doi: 10.2136/sssaj 2011.0148

Nugent C, Kanali C, Owende PMO, Nieuwenhuis M, Ward S (2003). Characteristic site disturbance due to harvesting and extraction machinery traffic onsensitive forest sites with peat soils. Forest Ecology and Management 180 (1-3): 85-98. - doi: 10.1016/S0378-1127(02)0o
628-X

Sensing 4: 1392-1410. - doi: 10.3390/rs4051392

Picchio R, Neri F, Petrini E, Verani S, Marchi E, Certini G (2012). Machinery-induced soil compaction in thinning two pine stands in central Italy. Forest Ecology and Management 285: 3843. - doi: 10.1016/j.foreco.2012.08.008

Pierzchala M, Talbot B, Astrup R (2014). Estimating soil displacement from timber extraction trails in steep terrain: application of an unmanned aircraft for 3D modelling. Forests 5: 1212-1223. - doi: 10.3390/f5061212

Pierzchala M, Talbot B, Astrup R (2016). Measuring wheel ruts with close-range photogrammetry. Forestry 89: 383-391. - doi: 10.1093/fores try/cpwoog

Pinard MA, Barker M, Tay J (2000). Soil disturbance and post-logging forest recovery on bulldozer paths in Sabah, Malaysia. Forest Ecology and Management 130 (1): 213-225. - doi: 10.1016/ S0378-1127(99)00192-9

Pirotti F, Travaglini D, Giannetti F, Kutchartt E, Bottalico F, Chirici G (2016). Kernel feature cross-correlation for unsupervised quantification of damage from windthrow in forests. In: Proceedings of the "XXIII ISPRS Congress". Prague (Czech Republic) 12-19 July 2016. The International Archives of the Photogrammetry, Remote Sensing and Spatial Information Sciences, volume XLI-B7, pp. 17-22. - doi: 10.5194/ isprs-archives-XLI-B7-17-2016

Puliti S, Orka HO, Gobakken T (2015). Inventory of small forest areas using an unmanned aerial system. Remote Sensing 7: 9632-9654. - doi: $10.3390 /$ rs70809632

Sheridan GJ (2003). A comparison of rubbertired and steel-tracked skidders on forest soil physical properties. Australian Journal of Soil Research 41: 1063-1075. - doi: 10.1071/SR02090

Spinelli R, Magagnotti N, Nati C (2010). Benchmarking the impact of traditional small-scale logging systems used in Mediterranean forestry. Forest Ecology and Management 260: 1997-2001. - doi: 10.1016/j.foreco.2010.08.048

Talbot B, Pierzchala M, Astrup R (2017). Applications of remote and proximal sensing for improved precision forest operations. Croatian Journal of Forest Engineering 38 (2): 327-336. [online] URL: http://hrcak.srce.hr/index.php? show=clanak\&id clanak jezik=281510\&lang=en Turner D, Lucieer A, Watson C (2012). An automated technique for generating georectified mosaics from ultra-high resolution unmanned aerial vehicle (UAV) imagery, based on structure from motion (SFM) point clouds. Remote
USDA Soil Taxonomy (1990). Keys to soil taxonomy ( $4^{\text {th }}$ edn). Soil Survey Staff, USDA Soil Conservation Service, Virginia Polytechnic Institute and State University, Blacksburg, VA, USA, pp. 422.

Venanzi R, Picchio R, Piovesan G (2016). Silvicultural and logging impact on soil characteristics in Chestnut (Castanea sativa Mill.) Mediterranean coppice. Ecological Engineering 92: 82-89. - doi: 10.1016/j.ecoleng.2016.03.034

Verhoeven G, Doneus M, Briese C, Vermeulen F (2012). Mapping by matching: a computer vision-based approach to fast and accurate georeferencing of archaeological aerial photographs. Journal of Archaeological Science 39: 2060-2070. - doi: 10.1016/j.jas.2012.02.022 Vericat D, Smith MW, Brasington J (2014). Patterns of topographic change in sub-humid badlands determined by high resolution multi- temporal topographic surveys. Catena 120: 164-176. - doi: 10.1016/j

Wallbrink PJ, Roddy BP, Olley JM (2002). A tracer bugdet quantification soil redistribution on hillslopes after forest harvesting. Catena 47: 179201. - doi: 10.1016/S0341-8162(01)00185-0

Wang DY, Qing CL, Guo TY, Guo YJ (1997). Effects of humic acid on transport and transformation of mercury in soil-plant systems. Water, Air, and Soil pollution 95: 35-43. - doi: 10.1007/ BF02406154

Warner WS (1995). Mapping a three-dimensional soil surface with hand-held $35 \mathrm{~mm}$ photography. Soil and Tillage Research 34: 187-197. - doi: 10.1016/0167-1987(95)00462-2

Williamson JR, Neilsen WA (2000). The influence of forest site on rate and extent of soil compaction and profile disturbance of skid trails during ground-based harvesting. Canadian Journal of Forest Research 30: 1196-1205. - doi: 10.1139/x00-04

Wood MJ, Moffat AJ, Carling PA (2003). Improving the design of slash roads used to reduce soil disturbance during mechanized harvesting of coniferous forest plantations in the UK. Journal of Forest Engineering 14: 11-23.

Woodget AS, Carbonneau PE, Visser F, Maddock I (2014). Quantifying submerged fluvial topography using hyperspatial resolution UAS imagery and structure from motion photogrammetry. Earth Surface Processes and Landforms 40 (1): 47-64. - doi: 10.1002/esp.3613 